\title{
NATURAL RESOURCES, ELECTRIFICATION AND ECONOMIC GROWTH FROM THE END OF THE NINETEENTH CENTURY UNTIL WORLD WAR II*
}

\author{
CONCHA BETRÁN \\ Universidad de Valencia ${ }^{\mathrm{a}}$
}

\begin{abstract}
RESUMEN
Las repercusiones de la nueva fuente de energía, electricidad, en el crecimiento económico de una muestra de países -Estados Unidos, Reino Unido, Francia, Italia, España y Canadá- caracterizados por sus diferentes dotaciones de recursos carboníferos es el principal objetivo de este artículo. La nueva energía, entre otras ventajas, redujo la dependencia de los recursos naturales de carbón al poder generarse a partir de diferentes energías primarias: agua o carbón. Con el fin de valorar la importancia de esta reducción de la dependencia del carbón, se presenta una base de datos de los recursos energéticos para los seis países, se muestra que los precios relativos de la electricidad frente al carbón fueron bajos en los países con mala dotación del segundo, y se detecta una relación negativa entre el precio relativo electricidad-carbón y el crecimiento económico. Además hubo una relación entre el ritmo de la electrificación industrial en los países sin dotación de carbón, su tasa de inversión, el aumento de la productividad del trabajo, el crecimiento económico y del sector manufacturero, y el cambio estructural.
\end{abstract}

\footnotetext{
* I am grateful to the comments received from the participants in the Economic History Workshop at the Universidad de Valencia (Departamento de Análisis Económico), from José E. Boscá, Albert Carreras, Sebastian Coll, Javier Ferri, Julie McGuinness, Jordi Palafox, Leandro Prados de la Escosura and Carles Sudrià, as well as to the financial support that I got from the research project DGYCIT PB 960800.

a Dpto. Análisis Económico, Campus dels Tarongers, Avda. dels Tarongers, s/n, Edifici Departamental Oriental, 46022 Valencia (Spain). mcbetran@uv.es
} 
Palabras clave: recursos carboníferos, electricidad, precios relativos electricidad-carbón, electrificación, crecimiento económico

\begin{abstract}
The impact that the new energy source, electricity, had on the economic growth of a number of countries -USA, UK, France, Italy, Spain and Canada- characterised by their different coal endowments is the principal objective of this article. The new energy, amongst its other advantages, reduced the dependence on natural resources of coal as it could be generated out of different primary energies: namely water or coal. In order to assess the importance of this reduced dependence, a coal-and-electricity energy database is presented for all six countries. We show that the relative prices electricity-coal were low in countries with poor coal endowments, and we find that there was a negative relationship between relative prices electricity-coal and economic growth. Moreover, there was a relationship between the industrial electrification process in countries with no coal deposits and their investment process, their labour productivity increase, their economic and manufacturing industry growth, and the structural change they underwent.
\end{abstract}

Keywords: coal resources, electricity, relative prices electricity-coal, electrification, economic growth

JEL Classification: N50, N70, O13, 014, O33, O43

\title{
1. INTRODUCTION
}

The objective of this article is to analyse the importance of one of the new energy sources, electricity, since the end of the nineteenth century until 1945, from the point of view of natural resource endowments ${ }^{1}$. Not all countries had good or equivalent endowments of coal, the energy-producing mineral of the nineteenth century, and for this reason not all of them had the same opportunities to use it, given that the transport cost was very high due to its weight in relation to its caloric power ${ }^{2}$. Electricity reduced the dependence on coal resources as it could be produced not only from coal but also from water.

${ }^{1}$ Landes (1969) attaches great importance to energy intensity in promoting economic growth. Wrigley (1988) explains how coal was able to increase the quantity and intensity of energy in relation to other organic sources, and therefore pushed the limits of growth further out.

${ }^{2}$ Wright (1990) and Nelson and Wright (1992) have studied the influence of the abundant stocks of coal and other minerals in relation to the economic success of the USA. 
Electricity had an enormous scope of applications: lighting, transport -railways, underground, tramways-, and power for traction. It facilitated the mechanisation of the majority of manufacturing processes because of the possibility of fractioning the use of energy and, thus, a more precise use of machines. An important factor from the point of view of the location of manufacturing was that this energy could be consumed far from the electricity production centre ${ }^{3}$. Thus, the advantages consisted of its ease of transmission, its capacity to be transported without major losses, its flexibility, its easy and efficient conversion into other energy sources, such as heat, light and movement, and its cleanness. Electricity meant greater freedom in the organization of work in the factory and greater flexibility in the use of energy, given that each electrical motor connected to a machine could work independently. The easy connection to the supply of electricity meant a reduction both in space and work dedicated to energy production as compared to the production of steam by the combustion of coal or the movement of the water turbine. The elimination of the shafts and belts to transmit energy allowed the organisation of production, or the division of labour, to change ${ }^{4}$.

The importance of this new energy source is analysed by means of an international comparison between economies both rich and poor in coal resources. Consequently, our first step will be to describe the natural resource endowments of these economies, the impact of their coal endowments on coal prices at colliery, and how their specific endowments, coal and water, affected their energy choices.

The second step will be to analyse the evolution of electricity prices for the different end consumers: industry, homes, services and transport, i.e. prices for electrical power, lighting, commercial use and traction. We have data for the USA, the UK and France, all of which had abundant coal resources, and for Italy, Spain and Canada, which had better water resources for most of the period 1890-1945. For the latter country, Canada, we only have data for the majority of the variables

${ }^{3}$ Hoover (1948) studies the importance of raw materials in the location of economic activity. Lösch (1954) and Isard (1956) consider that location was restricted to places that exhibited the minimum transport costs from coal deposits, as well as from the areas producing other raw materials, and to demand centres. The use of coal and electricity increased the tendency to locate activities close to where the demand was. See also Hoover (1948) and Krugman (1991).

${ }^{4}$ On the implications of these changes see Devine (1983). Electricity also forms part of what are called General Purpose Technologies (GPTs) because it provides great scope for improvement, opens up new opportunities with a wide variety of uses. It produces more than one kind of output, and also has a wide range of uses in the sense of the activities in the economy using the technology. See Bresnahan and Trajtenberg (1995), as well as the different works contained in the book edited by Helpman (1998). Recently, David and Wright (1999) have applied this concept to show the importance of electrification in the U.S. economy and its similarity with computer technology. Goldin and Katz (1998) also consider electricity the origin of the technology-skill complementarity of the twentieth century. 
from 1930 onwards. We haven’t found electricity prices for all of these categories and for all countries and, for that reason, we present the price series available for each country in order to show the differences among them. Because there is a similar trend or behaviour among prices, we choose the lighting price series to compare it with coal, representative of the alternative energy source, steam power. As our aim is to highlight the relationship between natural resource endowment and energy uses, we will look at the relative prices electricity-coal to show the advantages electricity presented for the countries with poor coal endowments.

The third step will be to estimate the impact of these differences on economic growth. We find that there was an inverse relationship between economic growth and the relative price electricity-coal. The countries with low relative prices electricity-coal grew more during this period.

The fourth step will consist of analysing the effects of the new energy on industrial electrification and, consequently, on investment and economic growth, especially during the first third of the twentieth century. The importance of the new energy source can be seen by observing the process of industrial electrification, its most important consumer, and where electricity competed with steam. Electrification advanced more rapidly in countries where the new energy opportunities were greater. There was also a relationship between the investment ratio -investment over income- and electrification on one hand and between these two variables and the growth rate of the manufacturing sector and the economies of countries without coal endowments on the other. The conclusions show the relevance of the new energy source for economic growth, above all, in countries poor in coal resources.

\section{NATURAL RESOURCES AND ELECTRICITY}

The most important energy sources during the nineteenth century and the first half of the twentieth century were coal, water and mineral oil. Not all countries had good and abundant coal deposits, and the cost of extraction could differ widely depending on the coal seams. The coal resources of a country were important because of the high transport cost of coal, which, in turn, reflected its low energy potential per weight unit with the extraction and transportation techniques then used.

Waterpower resources did not reach a similar importance in the $19^{\text {th }}$ century. The disadvantages of waterpower were its dependence on seasonal weather conditions which determined the availability of the water, its lower efficiency as a power source, and also that industries often had to be located in places far from markets or demand.

In that way, electricity changed the possibilities of the energy supply schedule of countries. As it was secondary energy it could be produced from coal 
-thermoelectricity-, but also from water -hydroelectricity. The latter possibility favoured countries with good water resources both with and without coal resources. The important problem with hydroelectricity was its dependence on that the weather conditions provided enough water year-round with which to produce electricity. This problem, however, could be solved by constructing dams to stock and regulate water flow, even though this meant a substantially greater investment layout for the countries using hydroelectricity. Also, the possibility of transporting electricity over long distances, by means of the alternating current, reduced many inconveniences considerably, as it allowed for better administration of the water resources and allowed the different areas to receive the quantity of electricity they demanded. These improvements became even greater by creating electricity networks. Consequently, in the initial phase most electricity produced and consumed was thermoelectric and, later on, as the situation improved for the use of hydroelectricity, each country used one or the other depending on her natural resources. Thermoelectricity also improved with the introduction of the steam turbine, which increased the efficiency in the use of coal. It reduced consumption of coal per kWh produced. In the early stages, the greater part of electricity used was self-produced by communities or firms but by the second decade of the twentieth century this had been completely replaced by electricity utilities firms which provided electric fluid 5 .

Now we shall describe the natural resources characteristics of each country. First, we will focus on the coal reserves and the impact they had on the prices at colliery. Second, we will show how natural resource endowment, coal and water, affected the kind of primary energy used to produce electricity -thermo, from coal, and hydraulic, from water- and we will indicate the locations of these energy resources in the countries being compared in this study.

The accessible coal endowments available at that time can be proxied by the reserve estimates elaborated by the Geological Survey of Canada in a monograph prepared for the Twelfth International Geological Congress, which was held in Canada in 1913. These estimations are presented in Table 1, both in the form of total coal reserves and coal reserves per capita in each country. Wellendowed in coal were Canada and the US in North America and Germany, the UK, Austria and -in an intermediate position- France in Europe. The Northern European countries Denmark and Sweden and the Southern European countries Italy, Greece and Portugal all had poor coal endowments. Looking at coal quality, Spain and especially Italy lacked good quality coal; as for the cost of extraction, this was particularly high in France and Spain, due to the characteristics of its seams.

${ }^{5}$ For example in the USA, in 1909, two-thirds of electricity consumption was self-produced, but, by 1929, two-thirds were purchased. See Mortara (1934, p. 58). 
TABLE 1

ESTIMATES OF COAL RESERVES ABOUT 1913

\begin{tabular}{|rlr|lr|}
\hline Ranking & \multicolumn{1}{|c|}{ Countries } & Million tons & \multicolumn{1}{c|}{ Countries } & Tons per head \\
\hline 1 & United States & $3,838,657$ & Canada & 157,192 \\
2 & Canada & $1,234,269$ & United States & 39,328 \\
3 & Germany & 423,356 & Germany & 11,187 \\
4 & Great Britain and Ireland & 189,533 & Austria & 7,962 \\
5 & Austria & 53,876 & Great Britain and Ireland & 4,146 \\
6 & France & 17,583 & Belgium & 1,435 \\
7 & Belgium & 11,000 & Netherlands & 714 \\
8 & Spain & 8,768 & Spain & 433 \\
9 & Japan & 7,970 & France & 424 \\
10 & Netherlands & 4,402 & Hungary & 219 \\
11 & Hungary & 1,717 & Japan & 154 \\
12 & Bulgaria & 388 & Bulgaria & 81 \\
13 & Italy & 243 & Sweden & 20 \\
14 & Sweden & 114 & Denmark & 17 \\
15 & Denmark & 50 & Greece & 7 \\
16 & Greece & 40 & Italy & 7 \\
17 & Portugal & 20 & Portugal & 3 \\
& & & & \\
\hline
\end{tabular}

Source: Coal reserves from The Geological Survey of Canada (ed.) (1913). Population figures from Maddison (1995).

The differences of national coal endowments are reflected by the levels of coal prices at colliery (see Table 2). We find lower coal prices in the USA, the UK and Germany than in France and Spain, and these differences were substantial. We can see how in the case of France and Spain, where extraction costs were significantly higher, the prices at colliery were too. However, in France, contrary to Spain, the coal reserves were closer to the industrial centres, and these centres were also closer to other coal producing countries. Italy, due to her scarcity of coal, imported coal from the UK through Genoa, with the resulting difference in prices with respect to the other above mentioned countries (see Table 2).

Despite the reduction in transport cost at the end of the nineteenth century, resort to imported coal significantly increased its price. Coal is heavy and bulky in relation to its unit value ${ }^{6}$. Moreover, the differences in transport costs between

\footnotetext{
${ }^{6}$ See Harley (1989) for coal trade and freights. The reduction in cost was important. For example, the freight rates from Cardiff to Genoa in 1873-5 were 16 shillings (s.) per tonne, in 18909.75 s. per tonne and in 19138.67 s. per tonne. In the case of the freight rates from Cardiff to Lisbon, they were 9.5 s. per tonne in $1873-5,7.71$ s. per tonne in 1890 , and 7.04 s. in 1913. The freight rates from Cardiff to Bordeaux in 1873-5 were 11.00 francs per tonne (5s. per tonne), 6.90 francs per tonne in 1890, and 6.94 francs (3 s.) per tonne in 1913. See Jevons (1969, pp. 692-693).
} 
TABLE 2

COAL PRICES FOR SEVERAL COUNTRIES, 1890-1912

(In 1913 shillings)

\begin{tabular}{|c|r|r|l|l|l|l|}
\hline Years & UK & Germany & USA & France & Spain & Italy \\
\hline 1890 & 9.27 & 8.87 & 6.38 & 11.11 & 10.48 & 29.11 \\
1891 & 8.70 & 9.30 & 6.45 & 12.63 & 11.45 & 27.46 \\
1892 & 8.36 & 9.23 & 7.11 & 12.16 & 11.08 & 27.20 \\
1893 & 7.99 & 8.77 & 6.83 & 11.39 & 11.48 & 27.13 \\
1894 & 8.34 & 9.08 & 7.26 & 12.03 & 11.39 & 29.27 \\
1895 & 7.74 & 9.46 & 6.72 & 12.05 & 9.75 & 23.59 \\
1896 & 7.70 & 9.61 & 7.01 & 12.29 & 11.01 & 24.12 \\
1897 & 7.69 & 9.38 & 6.81 & 12.17 & 11.52 & 26.05 \\
1898 & 7.94 & 9.34 & 6.23 & 12.14 & 12.65 & 35.48 \\
1899 & 9.59 & 9.36 & 6.20 & 12.45 & 14.87 & 31.70 \\
1900 & 12.52 & 9.81 & 6.48 & 14.08 & 18.07 & 44.64 \\
1901 & 11.27 & 11.27 & 6.84 & 15.42 & 17.95 & 33.95 \\
1902 & 9.92 & 10.90 & 6.62 & 14.71 & 15.85 & 29.46 \\
1903 & 9.24 & 10.49 & 7.56 & 13.85 & 14.14 & 28.36 \\
1904 & 8.58 & 10.41 & 6.78 & 13.43 & 12.03 & 29.70 \\
1905 & 8.29 & 10.06 & 6.44 & 12.50 & 11.78 & 28.73 \\
1906 & 8.38 & 9.70 & 6.43 & 12.50 & 12.15 & 32.31 \\
1907 & 9.89 & 10.03 & 6.27 & 13.04 & 11.52 & 34.60 \\
1908 & 10.14 & 11.99 & 6.50 & 14.91 & 12.21 & 29.17 \\
1909 & 9.06 & 11.15 & 5.69 & 14.31 & 12.22 & 28.30 \\
1910 & 8.81 & 10.94 & 5.68 & 13.20 & 11.59 & 28.85 \\
1911 & 8.67 & 10.55 & 6.21 & 12.77 & 12.06 & 30.02 \\
1912 & 9.15 & 10.31 & 6.02 & 12.49 & 13.95 & 33.86 \\
\hline
\end{tabular}

Sources: The UK, Germany, the USA, France and Italy elaborated from Bardini (1994, p. 144) and from British Parliamentary Papers of 1911 and 1924. For Spain, calculated from Coll and Sudrià (1987, p. 432).

Note: In the cases of the UK, Germany, the USA, France and Spain, these are coal prices at colliery. For Italy it is the coal price in Genoa imported from the UK. We have deflated the prices into 1913 fixed prices with the Wholesale Prices Index of each country from Mitchell (1998). We have used the 1913 official exchange rate of 27.09 peseta/pound for Spain.

countries close to and far away from coal production centres persisted over time. In Table 3 the average freight rates from Cardiff to different ports in 1909-1911 are shown. The freight rates to the closest continental harbours were about 4.5 shillings (s.) per tonne on average, but they ranked from 5.5 s. to 7 s. per tonne to the Mediterranean. For example, in the case of Barcelona, the industrial centre of Spain, the rate was 7.42 s. per tonne, and in Genoa it was 7.08 s., both of them being amongst the highest ${ }^{7}$.

\footnotetext{
${ }^{7}$ Jevons (1969, p. 686).
} 
TABLE 3

COAL FREIGHT RATES FROM CARDIFF TO DIFFERENT PORTS IN 1909-1911, (Shillings per tonne)

\begin{tabular}{|l|l|c|}
\hline Country & Port & Average freight rate per tonne \\
\hline Spain & Barcelona & 7.42 \\
Italy & Genoa & 7.08 \\
Sweden & Stockholm & 5.08 \\
France & Bordeaux & 4.71 \\
Denmark & Copenhagen & 4.58 \\
Portugal & Lisbon & 4.57 \\
Germany & Hamburg & 4.00 \\
& Close European ports & 4.5 \\
& Mediterranean ports & $5.5-7$ \\
\hline
\end{tabular}

Source: Elaborated from Jevons (1915, reprinted version 1969, pp. 686, 692-693)

Taking a country poor in coal reserves, Italy, the price of British coal from the UK in Genoa in 1890 was 44 per cent higher than that in London, the highest coal price in the UK. It was 50 per cent higher in 1900, and 45 per cent higher in 1910. This proportion becomes threefold if we consider other places in Italy far from Genoa, and compare them to sites in the UK closer to the mines. ${ }^{8}$. If we take the coal price at colliery in the UK (see Table 2) and we add the cost of transport to Genoa, the final price triples in 1883, and doubles in 1912. As for Spain, another country with poor coal endowment, the price of coal from the UK in 1890 -including the cost of transport and tariffs- was 74 per cent higher than that in the British port where it was loaded -free on board but including the transport cost from the mines to the harbour-, 65 per cent higher in 1900, and 77 per cent higher in $1910^{9}$.

Natural resources also had effects on the type of electricity being produced in these countries when electricity eventually arrived ${ }^{10}$. In the case of the USA, the main thermoelectric power plants were located in the regions along the Mid-Atlantic coast and in the North-East-Central industrial belt. In 1932, they represented 57 per cent of total installed power, 65 per cent of the electricity production in the USA, and 70 per cent and 75 per cent of the installed power and production, respectively, of thermoelectricity ${ }^{11}$. The main hydroelectricity power plants clustered in the coastal regions of the Atlantic -New York State, Pennsylvania, Maryland, North and South Carolina, Georgia and Alabama- and along the Pacific -in

\footnotetext{
${ }^{8}$ Bardini (1994, pp.151-2)

${ }^{9}$ Calculated from Coll and Sudria (1987).

${ }^{10}$ We have followed the description of Mortara's study, as given in Mortara (1934)

${ }^{11}$ Mortara (1934, pp. 35-36).
} 
California. In 1932, the former regions represented 45 per cent of the hydroelectricity production, and California 30 per cent.

In the UK, as mentioned above, the coal resources were extensive and of good quality. This country had less access to waterpower with the exception of the Highlands in Scotland ${ }^{12}$. Even the locations of coal seams were favourable, as they were distributed all over the country. This created a great advantage in terms of low coal prices for the country as a whole. In the advent of electricity, the main primary energy source became steam to produce thermoelectricity, and small local plants were established close to the location of coal mines.

In France, however, the coal fields were located in the regions of Pas de Calais, the North, Lorraine -Moselle-, the Central Massif -Saint-Etienne, Creusot, Gard, etc.- and the Saar -between 1925 and 1935. National production represented around two-thirds of the needs of the country, and the rest was imported from countries near to centres of production and consumption. The coal mining districts mentioned above were important industrial centres, which, time passing, became users of thermoelectricity. Water resources were substantial in the regions of the Alps and the Pyrenees, both well endowed with high falls of little flow, and in the Central Massif, where there were wide rivers. These regions, situated far from the important coal seams, used hydroelectric energy and were centres of the electrochemical and the electrometallurgical industries, which require cheap and abundant supplies of electric energy. The proportion of thermoelectricity was 57.3 per cent, the remainder being hydroelectricity ${ }^{13}$.

The situation was worst in Italy because of the scarcity of coal and its low caloric power. As a result, coal had to be imported ${ }^{14}$. For that reason, electricity was generated by hydraulic power, once the problem of long distance transmission was solved by means of the alternating current. The most important hydraulic resources were concentrated in the Alps and the Po Valley, between the Alps and the Apennines in the North of the country. The regions endowed with the most important sources of waterpower were the Piedmont and Lombardy, the Po Valley -Adda, Adige, Ticino, Tevere, etc.--, the Venetia region and that of Umbria.

The situation was different in Spain. As we have seen in Table 1, the coal resources were better than those of Sweden and Italy, worse than those in the United Kingdom and Germany, and similar -in per capita terms- to the case of France. The problem was the quality of Spanish coal as well as its difficult extraction and, hence, its high cost of production. Moreover, the most important coal resources were located in the Asturias region, in the North of Spain, close to

\footnotetext{
12 Ibidem (p. 205).

${ }^{13}$ Ibidem (p. 121).

${ }^{14}$ On the implications of coal resources for Italian economic development until 1913 see Bardini (1997, 1998).
} 
the sea side but difficult to transport out because of the mountains that enclose the region. Given its inaccessibility, a substantial part of coal consumption was supplied through foreign trade with the inconvenience of high transport costs. Spain's hydraulic resources were better than its coal resources, but not as abundant as in Italy, Sweden, Norway or Switzerland. Falls were located in the Pyrenees and the Penibetic range. The rivers had small flows, but they did occupy high grounds, which represented an advantage for electricity production. The rivers with the best flow conditions were the Ebro, the Douro and the Tagus. The disadvantage of a low flow is that this makes it very much dependent on year over weather conditions, making a substantial investment in dams necessary to stock water ${ }^{15}$.

We have calculated the proportion of hydroelectricity and thermoelectricity in the total electricity production of each country. As shown in Figure 1, at the top of the countries using hydroelectricity were Canada, Italy and Spain. Hydroelectricity accounted for over 80 per cent of their electricity production. At the bottom, using less than 60 per cent, as already commented, were the coal intensive countries, i.e. the UK, the USA, and France, although, France had a lesser proportion of thermoelectricity.

FIGURE 1

HYDROELECTRICITY

(\% Hydroelectricity Production)

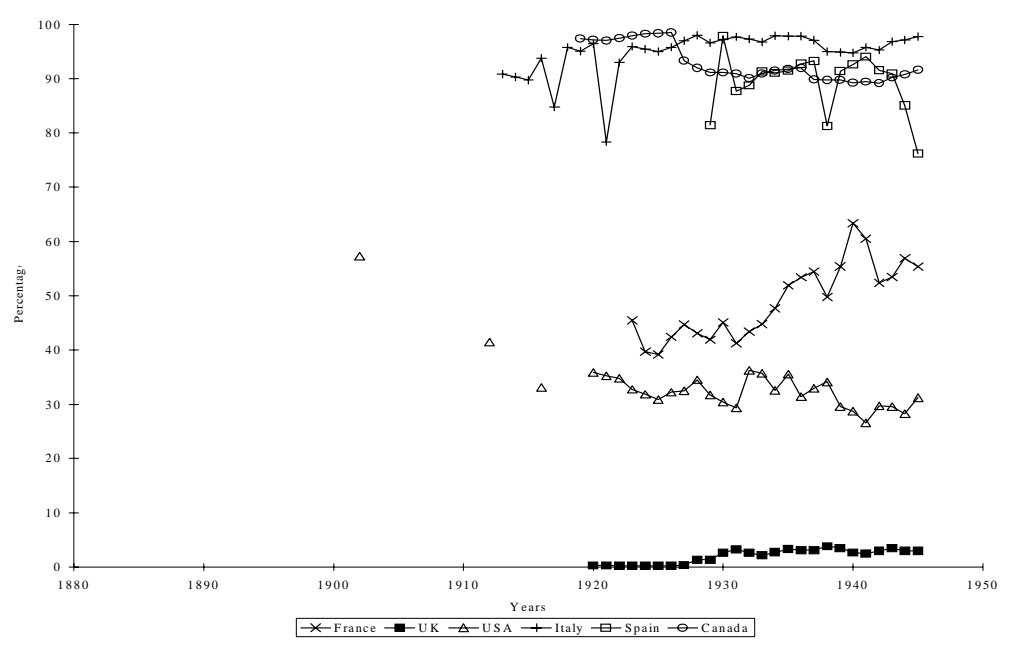

${ }^{15}$ For the case of Spain see the works of Sudrià $(1987,1990,1995,1997)$ and Maluquer (1987). For a less optimistic opinion on the influence of electrification in Spain, see Antolín (1999). 
The energy endowments of these countries can be quantified indirectly by establishing the distribution of their total energy consumption according to primary energy sources, expressed in coal equivalents. Table 4 depicts the proportions corresponding to solid fuels -coal-, liquid fuels -crude oil-, natural gas and hydroelectric power. A part of the solid fuels were used directly to produce steam. Thus, the UK did not use a significant amount of hydroelectric power; however, this was important in Italy, Canada and Spain. Crude oil was more important in the USA and Canada than in the rest of the countries mentioned here. The proportion of coal was greater in the UK and France.

Table 4 shows the transition to hydroelectricity during the period under consideration. The move to hydroelectric power in order of magnitude was important in Spain -from 2 per cent to 7.2 per cent-, in Canada-from 3.5 per cent to 7.8 per cent- and in Italy - from 6.9 per cent to 9.7 per cent. Spain was first because she started from a low level of 2 per cent in 1925. However, the UK, the USA and France had an extremely low participation in the first year (1925) and in the last year (1937). Participation was still below 2 per cent, in spite of a noticeable proportional increase in the French case.

TABLE 4

TOTAL ENERGY CONSUMPTION. DISTRIBUTION BY FUEL

(Based on coal equivalents)

\begin{tabular}{|c|c|c|c|c|c|}
\hline & Solid Fuels & Liquid Fuels & Natural Gas & $\begin{array}{c}\text { Hydroelectric } \\
\text { Power }\end{array}$ & Total \\
\hline \multicolumn{6}{|l|}{ UK } \\
\hline 1925 & 96.2 & 3.8 & - & - & 100 \\
\hline 1929 & 94.7 & 5.3 & - & - & 100 \\
\hline 1937 & 93.1 & 6.9 & - & - & 100 \\
\hline USA 1925 & 74.2 & 19.2 & 6.2 & 0.5 & 100 \\
\hline 1929 & 68.1 & 22.7 & 8.7 & 0.6 & 100 \\
\hline 1937 & 58.6 & 29.1 & 11.6 & 0.8 & 100 \\
\hline \multicolumn{6}{|l|}{ France } \\
\hline 1925 & 95.5 & 3.7 & - & 0.8 & 100 \\
\hline 1929 & 94.5 & 4.6 & - & 1.0 & 100 \\
\hline 1937 & 87.5 & 10.8 & - & 1.7 & 100 \\
\hline \multicolumn{6}{|l|}{ Italy } \\
\hline 1925 & 83.9 & 9.2 & 0.1 & 6.9 & 100 \\
\hline 1929 & 82.3 & 10.5 & 0.1 & 7.1 & 100 \\
\hline 1937 & 71.3 & 18.9 & 0.1 & 9.7 & 100 \\
\hline \multicolumn{6}{|l|}{ Spain } \\
\hline 1925 & 93.1 & 4.9 & - & 2.0 & 100 \\
\hline 1929 & 90.2 & 7.5 & - & 2.4 & 100 \\
\hline 1937 & 64.0 & 28.8 & - & 7.2 & 100 \\
\hline \multicolumn{6}{|l|}{ Canada } \\
\hline 1925 & 81.9 & 12.5 & 2.1 & 3.5 & 100 \\
\hline 1929 & 73.7 & 19.0 & 2.5 & 4.8 & 100 \\
\hline 1937 & 65.4 & 23.8 & 3.0 & 7.8 & 100 \\
\hline
\end{tabular}

Source: Darmstadler (1971), pp. 652 and following. 


\section{ENERGY PRICES. ELECTRICITY, COAL AND THEIR RELATIVE PRICES: THE DATA}

The data set presented in this section has been compiled from sources that differ from country to country. These sources are indicated in the Appendix included at the end of the article. The following sub-sections present and comment on the evolution of different energies prices.

\subsection{The evolution of electricity prices}

As commented above, there are different kinds of prices for different users: household, power, traction, etc., and also differences in the source from which these prices can be taken: electricity rates, average prices, and revenues over sales. In the electricity market there were few companies that offered a complete spectrum of electricity services. Consequently, the market was not competitive and the market power of certain companies could have allowed for non-competitive pricing practices. At the same time the electricity market was regulated by government, electricity being considered a public service.

Therefore prices depended on regional companies and government regulation. Though regulation may have reduced incentives to investment, the parallel protection of the government to the property rights on the electric utilities of these companies encouraged them to invest. On the other hand, regulation meant that the prices did not reflect textbook oligopoly prices. At least this was the case of the USA, where prices ended up being rates charged to consumers by stateregulated regional utilities, although at the beginning there were local regulations on electric utilities. Therefore we should not interpret the regional oligopoly as being entirely negative for electrification.

Be it as it may, since the economic agents had to take economic decisions with the prices fixed by companies, we will analyse the effects of these prices for the economy. For example, David and Wright (1999) have stressed that for the USA the real momentum of electrification came after WWI, when the rates charged to consumers by state-regulated regional utilities fell substantially in real terms due to the gains in efficiency in electricity generation. As we will see, this also happened in the rest of countries included in this study.

The price policy of the electricity companies varied depending on the kind of consumers it supplied. Industrial consumption was the biggest, followed by the household and traction. We can show this pattern for the countries we have data for. In the UK, industry consumption in 1929 was 60.8 per cent of total consumption; in the US, this percentage was 53.67, and in Italy, in 1931, it was 


\section{ENERGY PRICES. ELECTRICITY, COAL AND THEIR RELATIVE PRICES: THE DATA}

The data set presented in this section has been compiled from sources that differ from country to country. These sources are indicated in the Appendix included at the end of the article. The following sub-sections present and comment on the evolution of different energies prices.

\subsection{The evolution of electricity prices}

As commented above, there are different kinds of prices for different users: household, power, traction, etc., and also differences in the source from which these prices can be taken: electricity rates, average prices, and revenues over sales. In the electricity market there were few companies that offered a complete spectrum of electricity services. Consequently, the market was not competitive and the market power of certain companies could have allowed for non-competitive pricing practices. At the same time the electricity market was regulated by government, electricity being considered a public service.

Therefore prices depended on regional companies and government regulation. Though regulation may have reduced incentives to investment, the parallel protection of the government to the property rights on the electric utilities of these companies encouraged them to invest. On the other hand, regulation meant that the prices did not reflect textbook oligopoly prices. At least this was the case of the USA, where prices ended up being rates charged to consumers by stateregulated regional utilities, although at the beginning there were local regulations on electric utilities. Therefore we should not interpret the regional oligopoly as being entirely negative for electrification.

Be it as it may, since the economic agents had to take economic decisions with the prices fixed by companies, we will analyse the effects of these prices for the economy. For example, David and Wright (1999) have stressed that for the USA the real momentum of electrification came after WWI, when the rates charged to consumers by state-regulated regional utilities fell substantially in real terms due to the gains in efficiency in electricity generation. As we will see, this also happened in the rest of countries included in this study.

The price policy of the electricity companies varied depending on the kind of consumers it supplied. Industrial consumption was the biggest, followed by the household and traction. We can show this pattern for the countries we have data for. In the UK, industry consumption in 1929 was 60.8 per cent of total consumption; in the US, this percentage was 53.67, and in Italy, in 1931, it was 
$74.54^{16}$. Prices were higher for household use because it involved a higher expenditure in distribution and because of its short duration and its peaks during the same periods of time. The following paragraphs describe the evolution of the different prices for the countries for which we have data. Also, we will also show lighting prices for all countries in Figure 2.

FIGURE 2

REAL ELECTRICITY PRICES

(1913 prices)

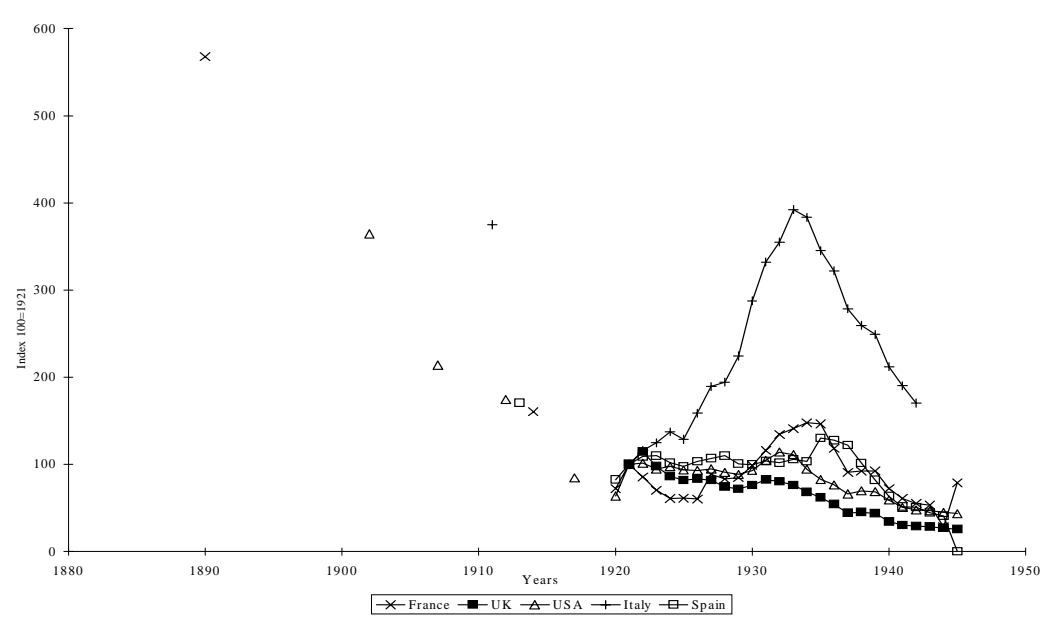

The analysis of price evolution yields two major findings. First, in every country for which we have data, the evolution is the same for the different users, the sole differences being the level -in the case of the USA and Canada- and the inclination of the slope -in the case of the UK. The lighting prices to households, which we have for all of our countries, were higher than other prices -for power and traction. Thus, even if we do not have data for every different use in France, Italy and Spain, we can use lighting prices as a proxy for the general evolution of electricity prices in order to compare it with that of the alternative energy, steam, which was biased against electricity. Second, the evolution of prices from the beginning of

${ }^{16}$ See the sources of statistics in the Appendix. The proportion also varied depending on the level of the consumption of electrical home appliances which increased the lighting use, and which were well developed in the USA. 
the series, prior to WWI, follows a similar path in every country, that is, it shows a fall in real prices. In the 1920s prices were more or less stable in the USA, the UK and Spain; in France, they decreased from 1921 to 1927 and increased afterwards, and in Italy they increased until 1933. In the 1930s, two trends are apparent, an increase in prices until around 1933, and a fall afterwards.

Another important aspect to highlight are the different periods of time for which we have data in each country, as well as the origins of the source. In the case of the UK, for which we have series of electricity prices from sales over incomes, the starting point of the series is 1921. Also in Canada, with the same kind of calculated prices, the series start in 1930. For the rest of the countries we have some data prior to 1913, and the sources are average prices, except for Italy, where the data consists of electricity rates. These differences in sources may have an effect on the comparisons across countries.

\subsection{The evolution of coal prices}

The principal alternative energy to electricity was steam. Therefore, we may approach the cost of this energy by using the price of coal. With regard to coal prices, there are different qualities and kinds of minerals. The series presented in the yearbooks and official statistics vary across countries and perhaps this indicates which coal was more generally used in each of them. Moreover, this depended very much on their natural resource stocks ${ }^{17}$.

In Figure 3, we can observe an increase in the price of coal in 1920 in all countries, except for a pronounced increase of Spanish prices during WWI. The explanation for the latter could rest in the fact that Spain was neutral in the conflict and did not have enough coal to supply the necessities of her economy due to her poor coal endowment. Also, we can find a reduction of prices to pre-WWI levels in all countries during the twenties, as well as certain stability afterwards. The exceptions were Spain -although the evolution there was stable- and the USA -where prices grew in the second part of the 1920s and remained above pre-WWI levels. Prices fell everywhere else in the thirties, with the exception of the UK.

The international coal market was stagnant. There was an expanding market prior to WWI, but afterwards demand declined and this decline was further accentuated by an increase in the efficiency in the use of coal. The decrease in demand was due to the appearance of new energy sources, electricity and mineral oil, and the consequent substitution, for example, from coal-burning to oilburning ships and from steam engines to electric motors. Although the

\footnotetext{
${ }^{17}$ We can see in the Appendix how these sources can differ.
} 


\section{FIGURE 3}

REAL COAL PRICES

(1913 prices)

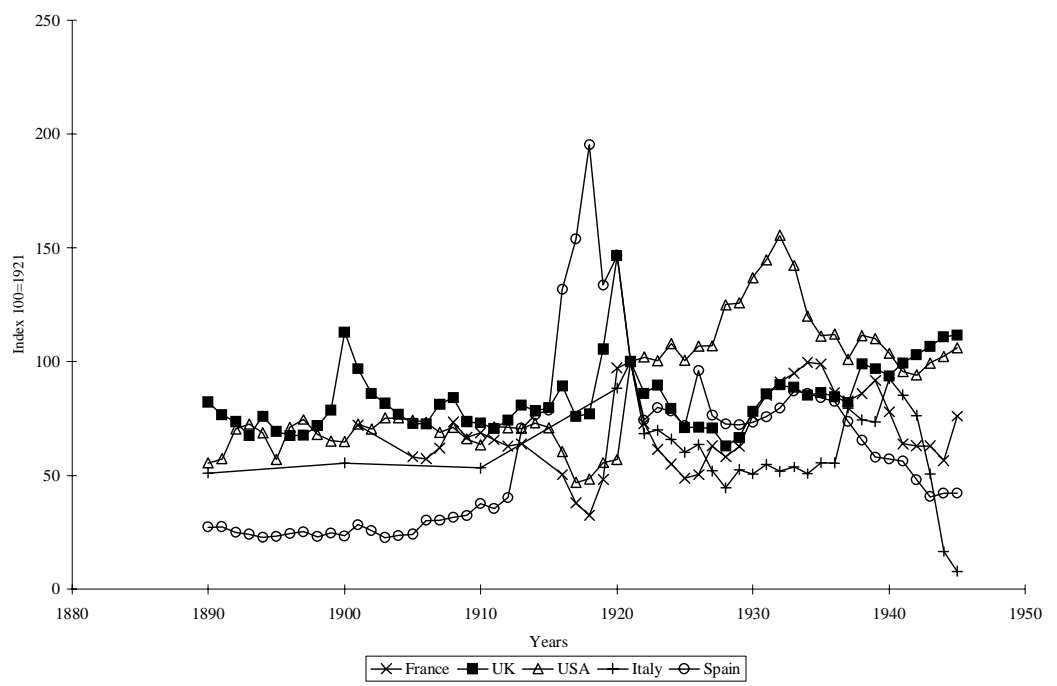

thermoelectric industry did increase its demand for coal, this coincided with a lower total demand for this mineral. There were important recessions in the coalintensive industries, such as the iron and steel and shipping industries. In addition, there was also an improvement in the techniques of coal use, the steam turbine or higher fuel efficiency in blast furnaces, which reduced the consumption of coal per kWh.

\subsection{Relative prices electricity-coal}

Having looked at the evolution of the prices of electricity and coal, we are now moving on to analysing their relative prices in the countries under study ${ }^{18}$. Thus, we are comparing a primary energy source, coal, with a secondary source, electricity. In the production of electricity coal was also an input, so we are also measuring the improvement in efficiency in thermoelectricity and thus how this favoured electricity.

${ }^{18}$ As we have already mentioned, we use lighting electricity prices to this aim, as we have data on them for all countries. However, as commented above, we depend on different sources for electricity prices which could affect the comparisons. 
FIGURE 4

RELATIVE PRICES ELECTRICITY-COAL

(Ton/kWh)

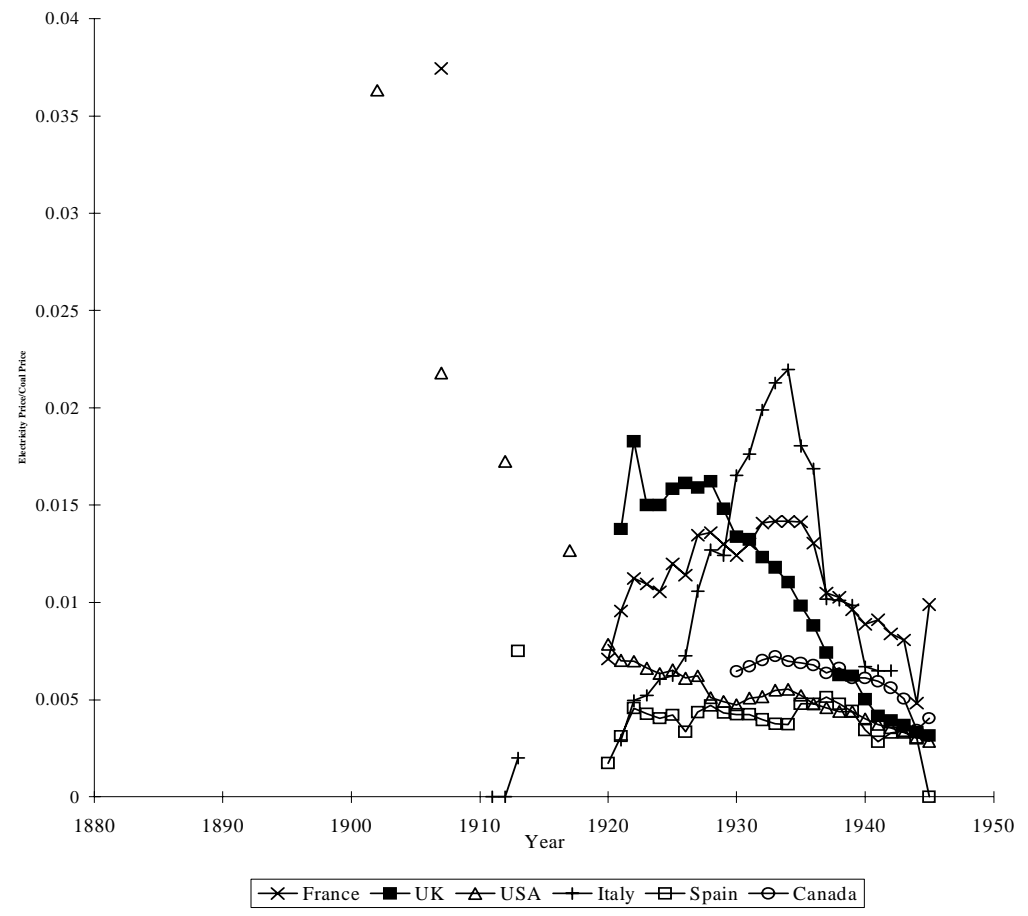

The relative price between electricity and coal determines the quantity of coal that we can buy with a unit of electricity, in short, the number of tonnes per $\mathrm{kWh}^{19}$. The more expensive coal is with respect to electricity, the lower the quantity of coal will be that we are able to buy per unit of electricity, and vice versa. In general, the relative prices were lower in the countries that lacked good endowments of coal than in those rich in coal resources. In Figure 4, we can see the relative prices in some of these countries: France, Italy, the USA, the UK, Spain and Canada. We can observe how in countries endowed with better coal resources, the level of relative prices was higher than in countries with less resources or with much better conditions for hydroelectricity in relation to steam or thermoelectricity. The first group comprises the UK, France and the USA and the

${ }^{19}$ The relative prices, electricity over coal, have been used by Svennilson (1954). 
latter Italy, Spain and Canada, although in Italy the relative prices increased substantially during the 1920 s.

We will now turn to comment on the evolution of these relative prices country by country. In general terms, there was an important fall around WWI, and afterwards the evolution depends on each individual country. The USA exhibited falling relative prices over the whole period, this being more accentuated at the beginning of the twentieth century. In the case of the UK, relative prices started to decrease in the 1930s. France also experienced an important reduction towards the beginning of the century, although prices increased in the 20s and did not decrease until the mid 30s. However, there was a spectacular change in Italy, with the relative prices increasing from 1920 to 1934 in relation to the lower level of the 1911 to 1920 average. From 1934 up to the end of the series, the relative prices again experienced a steep descent. A similar fall happened in Spain during WWI, but the relative prices remained stable during the 20s and 30s. The rise of the relative prices in Italy was due to the increase in electricity prices in the 20s, which endured until $1933^{20}$, and to the fall in coal prices from 1921 to 1930 . This fall did not happen in Spain in the 20s, although coal prices fell after 1933.

\section{ELECTRICITY AND ECONOMIC GROWTH}

Electricity presents the advantage, compared to other energies, of the great variety of uses: power, lighting, traction, and so on. Gas, on the other hand, could only be used for lighting, so it was a competitor in the early years, but soon the relative prices favoured the new energy ${ }^{21}$. In the case of traction, there was competition with another new energy at that time, oil, and the relative price changes did not favour its use in traction ${ }^{22}$. However, electricity was very important in the new urban means of transport such as the subway and the tramway. The most important competitor for power transmission and also for heating was steam. This notwithstanding, electricity could meet the new demands not satisfied by the old energies, such as the demand from the small craft manufacturers or from the high value-added industries that had not been able to mechanise beforehand. This fact was very important for the increase in productivity of these kinds of manufactures. Furthermore, the new machinery, less heavy and more precise due to new steel

\footnotetext{
${ }^{20}$ Giannetti $(1985,1986)$ says that after WWI inflation caused important financial problems to the electrical companies, due to their big investments in installed capacity during WWI, so that they had to increase the electricity rates. The demand was completely inelastic. See also Storaci and Tattara (1998) for the financial problems of companies.

${ }^{21}$ Regarding such competition see Arroyo (1996) and Sudrià (1983) on the Spanish case and Hannah (1979) for the British one.

${ }^{22}$ Hannah (1979, pp. 157-159).
} 
alloys, as well as the new possibilities it opened for organising production, allowed for important improvements in industrial productivity. Among them the most relevant examples are provided by the industries using continuous-process and batch technologies ${ }^{23}$. Added to this were the previously mentioned advantages of easy transmission, flexibility and cleanness ${ }^{24}$.

There are several factors which contributed to the rapid development of electricity ${ }^{25}$. First, the quick succession of different inventions and developments that improved the generation and application of electricity ${ }^{26}$. Second, at about the time of WWI there was an increase in the efficiency of thermal power stations, which accelerated their spread. Third, and most important, there was the invention of high voltage current that allowed the transmission of energy over long distances $^{27}$. The latter allowed the consumption of electricity to increase as it could be used in places other than those of production. Fourth, as mentioned above, David and Wright (1999) have highlighted the importance in the fall of US real electricity prices during WWI, and we have seen in the above section that this also happened in the countries under study.

This section estimates the impact of the new energy, electricity, measured in terms of relative energy prices on economic growth. We have looked at the relative prices of both energies -electricity and coal- for the countries submitted to our investigation. As it seems, there were advantages for the countries poor in coal reserves in terms of opportunities to mechanise and, hence, to improve industrial productivity. The advance of electrification in the manufacturing sector, which we will review in the next section, due to lower relative energy prices, must have had an impact on the increase in productivity in industry ${ }^{28}$ and, consequently, on economic growth. Now, we want to look at the effect of electricity by looking at the relationship between relative prices electricity-coal and economic growth during the period 1921-1945. We will contrast whether low relative prices electricity-coal stimulated the investment in the electrification process and influenced economic

${ }^{23}$ See Goldin and Katz (1998).

${ }^{24}$ There is a very good explanation of all of these advantages in Devine (1983). On the effects on productivity growth, see the US case in Woolf (1984), David and Wright (1999) and that of Canada in Wylie (1989).

${ }^{25}$ See Hugues (1983) for the changes in the configurations of the electric power system in 1880-1930, from the intercity lighting system to regional power systems. His explanation includes technical, scientific, economic and political factors.

${ }^{26}$ See Svennilson (1959).

${ }^{27}$ The first transport of energy over a long distance took place in 1873, and in 1882 using the high voltage current. The transformation of the current to high voltage was invented in 1884, but not until 1893 was the high voltage current considered better than the continuous current, because the importance of long distance transport had not yet been measured. This notwithstanding, the beginning of the twentieth century witnessed the establishment of long distance transport of electricity.

${ }^{28}$ See Woolf (1984) and Devine (1983). 
growth. We have constructed a panel data with five of the countries ${ }^{29}-$ France, the UK, the USA, Italy and Spain- and for five periods, namely: 1921-25, 1925-29, 192935, 1935-40 and 1940-45. These include the periods of rapid advance of electrification. We have regressed the growth of GDP per capita on the initial level of GDP per capita, the ratio of investment over GDP, taken as a proxy for capital accumulation, the schooling ratio -primary school enrolment- and the literacy ratio, taken as two proxies for human capital, and the relative prices of both energies, as in the following equation:

$$
\mathrm{GY}=a+b \mathrm{Y}_{\mathrm{t}-1}+c \mathrm{INV}+d \text { Education }_{\mathrm{t}-1}+e \mathrm{PP}_{\mathrm{t}-1}+u_{\mathrm{t}}
$$

GY is the annual growth rate of GDP per capita, $Y_{t-1}$, the GDP per capita in the initial level for each period in natural logarithms, INV the investment share on GDP, which is an average for each period, Education the schooling and literacy ratio in the initial level for each period, and $\mathrm{PP}_{\mathrm{t}-1}$, the relative price electricity-coal in the initial level for each period ${ }^{30}$.

In Table 5 we can see the results of the relevant regressions. In our first regression we consider the initial GDP per capita, the investment share on GDP, schooling, the significant dummy of the UK, and we have added the period dummies which include the 1929 crisis and WWII ${ }^{31}$. The UK dummy captures the omitted variables related to the differences in the level of development: structural change, institutions and other factors that can influence economic growth. We have tested with schooling and literacy ratios, but literacy is correlated with GDP per capita. In the second regression, with have tried with schooling and, in the third, with literacy, to which we have added the relative prices electricity-coal.

We have found a negative sign for the initial level of per capita GNP (nonsignificant) which means a relative convergence after controlling for the rest of the variables, the UK dummy and the period dummies. Also we find a positive sign of INV (significant), although not very high ${ }^{32}$, and of schooling (nonsignificant). In the second regression, a negative coefficient of the relative prices electricity-coal has been found (significant). In the third one we have obtained the same result regarding the literacy variable: i.e., literacy is not significant. The relationship between relative prices electricity-coal and the growth of income per

\footnotetext{
${ }^{29}$ We have not included Canada because we only have data for the 1930 s.

${ }^{30}$ The sources and definitions of variables appear in the data appendix.

${ }^{31}$ Period dummies are not statistically significant. We have only considered the significant region dummies -i.e. the UK dummy- in order not to lose degrees of freedom. However, although relative prices always present a negative sign with all the dummies, they are only significant when we include the significant dummy of the UK. Perhaps this is due to the fact that this is the sole country exhibiting a positive economic growth in all five periods, the rest showing negative ones above all during WWII. Besides, there must be omitted variables that influenced economic growth in the UK.

${ }^{32}$ Compare with the results obtained by Barro (1991) and De Long and Summers (1991).
} 
TABLE 5

RELATIVE PRICES AND ECONOMIC GROWTH

\begin{tabular}{|l|c|c|c|}
\hline \multicolumn{5}{|c|}{ Dependent variable: GDP Per Capita Growth } \\
\hline Period: 1921-45 \\
\hline C & $\mathbf{( 1 )}$ & $\mathbf{( 2 )}$ & $\mathbf{( 3 )}$ \\
ln Y1 & 0.313 & 0.368 & 0.056 \\
& $(0.848)$ & $(1.190)$ & $(0.199)$ \\
INV & -0.056 & -0.063 & -0.018 \\
& $(-1.092)$ & $(-1.469)$ & $(-0.371)$ \\
Literacy & 0.006 & 0.007 & 0.008 \\
& $(2.126)$ & $(2.685)$ & $(2.841)$ \\
Schooling & & & 0.00002 \\
& & & $(0.012)$ \\
PP1 & 0.001 & 0.001 & \\
& $(0.996)$ & $(1.206)$ & -2.917 \\
DUK & & -2.952 & \\
& $(-2.044)$ & $(-2.127)$ & 0.096 \\
D2935 & 0.060 & 0.083 & $(3.902)$ \\
& $(2.809)$ & $(3.209)$ & -0.011 \\
D3945 & -0.01741 & -0.011 & $(-1.001)$ \\
& $(-1.448)$ & $(-0.952)$ & -0.017 \\
R2 centered & -0.01739 & -0.016 & $(-0.585)$ \\
N (usable obs.) & $(-0.579)$ & $(-0.605)$ & 0.493 \\
& 0.437 & 0.513 & 24 \\
\hline
\end{tabular}

Note: OLS estimation corrected by heteroskedasticity, White Method. The t-statistic figures in parenthesis.

Variables: Endogenous variables, annual growth rate of GDP per capita. Exogenous variables: Y1, initial per capita GDP in natural logs; INV, investment share on GDP; PP1, initial relative price: electricity over coal; Education: schooling and literacy in the initial level; DUK, dummy for the UK; D2935, dummy for the period 1929-35; and D3945, dummy for the period 1939-45.

capita is negative and statistically significant. This means that the countries with low relative prices electricity-coal, that is, where electricity was cheaper relative to coal, grew more during this period. Thus, the new energy had a positive effect on economic growth and was important for countries without good coal endowments.

\section{THE IMPORTANCE OF THE NEW ENERGY SOURCE: INDUSTRIAL ELECTRIFICATION}

Now we shall turn to the impact of the new energy on the evolution of the industrial electrification process. Industry was where the most important demand at that time came from, and where electricity competed with other energies. 
The degree of electrification depended on several main factors: the possibility and the opportunity for investment in the new energy as well as the energy price. On one hand, the opportunity for investment depended on whether useful capital was still being employed in the old energy, above all in the countries with low coal prices. Nevertheless, it was also necessary to have resources to invest and thus it also depended on the macroeconomic cycle. On the other hand, the electrification process was not fully underway until real electricity prices fell after WWI, when investment in large generator plants allowed for economies of scale, and when there was more coordination among plants by way of investment in electricity networks. Economies of scale were thus potentially greater in the higherincome countries.

In Table 6 we can see the degree of electrification in the industrial sector, as indicated by the proportion of electric motor-driven machinery on total machinery, in terms of horsepower. We show these data for the first third of the twentieth century -1900, 1913, 1925, 1929 and 1938- and for 11 countries in Europe, the USA, Canada and Japan. In this way, we can observe the evolution of the electrification process over time. The main advance in this process happened between 1913 and 1925 for all the countries studied. In this period electrification improved substantially, over 50 per cent, in the UK and France slightly less so with 49 per cent. The countries with better water resources in relation to coal began the electrification of industry earlier. For example, the USA and Sweden achieved a level of 77 per cent, having started from 40 per cent and 48 per cent respectively in 1913, and Italy reached 74 per cent, when in 1913 it had been only 48 per cent. In 1929 the level of industrial electrification was rather high, greater than 75 per cent with the exception, again, of the UK -61 per cent or 66.3 per cent depending on the source- and Germany -70 per cent ${ }^{33}$. In 1938, in the countries for which we have data, the percentage rose to more than 85 per cent. We do not have data for the UK in this year.

The following paragraphs concentrate on electrification by manufacturing sector, in order to highlight the differences among sectors and countries, independent on the structure of the economy. The data relevant for this comparison appear in Table 7. A second objective of this table is to compare Spain with other countries, since we do not have overall data for Spain, but only for some manufacturing sectors. In the USA the least electrified sector was woodworking -58.3 per cent-, as was also the case in Sweden and Norway, and the most electrified sectors were publishing and rubber: about 95 per cent. Publishing was highly electrified in Germany, Italy, Switzerland and Norway. The

${ }^{33}$ We do not have data for France for 1929, but they were perhaps low too. 
TABLE 6

ELECTRIFICATION

(\% Electric motor driven machinery/total horsepower)

\begin{tabular}{|l|c|c|c|c|c|}
\hline Country & $\mathbf{1 9 0 0}$ & $\mathbf{1 9 1 3}$ & $\mathbf{1 9 2 5}$ & $\mathbf{1 9 2 9}$ & $\mathbf{1 9 3 8}$ \\
\hline UK $^{\mathrm{a}}$ & & 23 & 49 & $61 / 66.3^{\mathrm{b}}$ & \\
France & & & 48.8 & 70 & \\
Germany & \multirow{3}{*}{11.6} & $36 / 38.9^{\mathrm{c}}$ & 77 & $79.1 / 82.3^{\mathrm{c}}$ & $85 / 89.84^{\mathrm{c}}$ \\
USA $^{\mathrm{a}}$ & & & 67 & & \\
Canada & & 48 & 77 & 82.5 & 89 \\
Sweden & & & & 87.8 & \\
Switzerland & & 32 & 67 & 73.8 & 87 \\
Norway & & 47.7 & 74 & $77.8 / 79^{\mathrm{d}}$ & 88 \\
Finland & \multirow{2}{*}{17.5} & 30.6 & 62.2 & 69.4 & 83.3 \\
Italy & & & & \\
Japan $^{\mathrm{a}}$ & & & &
\end{tabular}

Sources:

${ }^{\mathrm{b}}$ the UK: first figure as calculated from Svennilson (1959); second one from Mortara (1934).

c the USA: first 1913 figure from Mortara (1934); second one (in 1914), from Schurr \& Netschert (1977).

c the USA: first 1925 figure from Mortara (1934); second one from Schurr \& Netschert (1977).

c the USA: first 1938 figure from Myllyntaus (1991); second one (in 1939) from Schurr \& Netschert (1977).

${ }^{d}$ Italy: 1900 and 1913, from Bardini \& Hertner (1992); 1929, first figure (in 1927) from US Department of Commerce; second one (in 1929), from Mortara (1934).

Germany: 1925 figure from Mortara (1934); Japan from Nakamura \& Odaka (2003, p. 24); The rest from Myllyntaus (1991).

Note: The years are for ${ }^{a}$ the UK $(1912,1924)$, the USA (1904, 1926, and 1937), Italy (1898, 1911, 1927) and Japan (1914, 1924, 1928 and 1937).

chemical industry was also highly electrified if we include the electrochemical sector, above all in the countries well endowed with water resources such as Switzerland, Norway, France -in the Alps- and Germany. Something similar happened in the metal constructions sector related to the electrometallurgical sector in Italy, Switzerland, Sweden and Norway. However, food, iron and steel and even the textile sectors -though not apparel- were less electrified in Germany, the UK -where food was highly electrified-, France and Italy -where the textile sector was highly electrified-, and outstandingly so in the USSR -23.8 per cent-, where economic policy did not favour the consumption goods industry but the equipment goods industry. These manufacturing sectors had low-income elasticity demand at that time and this may have delayed investment. 
NATURAL RESOURCES, ELECTRIFICATION AND ECONOMIC GROWTH

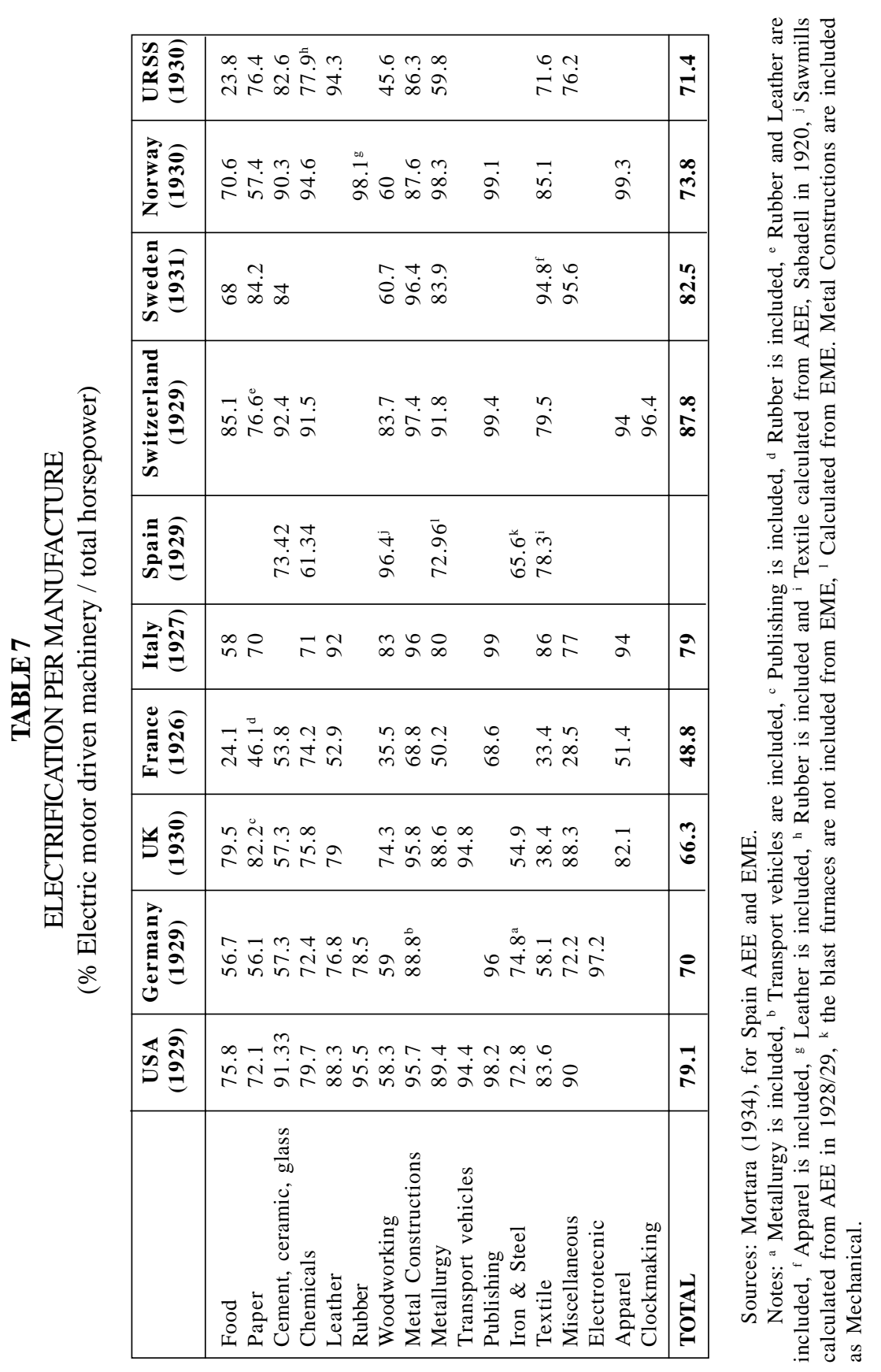


In the case of the less electrified countries such as France, the UK and Germany, we can see in Table 7 how the traditional sectors -cement, ceramics and glass, iron and steel, and textiles- were noticeably less electrified than their equivalents in the rest of the countries. However, in the case of France the majority of sectors presented low degrees of electrification with the exception of the chemical industries located near water resources. In the case of Germany this also happened in the food and paper sectors. And, in the UK, the sectors related to the new technologies of the second industrial revolution were more electrified.

In the case of Spain, there are no data for the whole of the industry, but only for certain branches ${ }^{34}$. In textile manufacturing, which represented a high proportion of the total industrial sector, the electrification process experienced a big advance during the twenties, and the same happened in the woodworking sector and workshops. In 1929, in the chemical industries, where data is very incomplete, 64 per cent of horsepower was produced by electric motors, while in 1913 most of these were driven by steam and, in 1922, the electric powered machines began to exceed those powered by steam. The electrochemical sector had not advanced very much in Spain as this would have required lower electricity prices. 74.9 per cent of the horsepower used in the artificial cement industry was of electric origin; however, in the natural cement industry, which was less important, this declined to 60.4 per cent. The iron and steel industry was located near the coal deposits, and great investments were needed to electrify this industry. Electrification took place in the rolling stage, but was much lower in the electric blast furnaces employed to produce new special steels, where cheaper energy is needed. In 1929, 69.1 per cent of total machinery, excluding furnaces, consumed electricity as compared with 34.5 per cent in 1913. In the metallurgy industry, the participation of electric motors in the production of copper, lead, zinc and aluminium was 65 per cent, 87, and 100, respectively, in 1929.

Comparisons are difficult because the division by manufacturing sub-sectors is not homogeneous, and because in the case of Spain we have only partial data. However, despite these difficulties we shall discuss the Spanish case. In Spain, electrification in the textile and iron and steel industries was not far behind that in other countries. It was also important in the woodworking, cement, ceramic and glass industries, though the data are incomplete for the chemical industry. According to the information we have, we can say that the process of electrification, under way at that time in Spain, was not retarded by her lower level of economic development.

In short, an advanced electrification process is observed in the countries less endowed with coal, such as in Spain, Italy and the Northern European countries, in spite of their different levels of economic development. On the other hand, the

\footnotetext{
${ }^{34}$ The sources are in the Data Appendix.
} 
countries that were the last ones in electrifying their industries were the countries blessed with better coal endowments, such as the UK, Germany and France. The exception among them corresponds to the USA, which had good endowments of both resources.

\section{INDUSTRIAL ELECTRIFICATION AND ECONOMIC GROWTH: AN OPPORTUNITY FOR THE COUNTRIES BADLY ENDOWED WITH COAL.}

Now, we are interested in finding out the importance, in terms of opportunities of increasing productivity and growth, that the electrification process had in the countries not well endowed with coal fields. To this end, we are going to look at the relationship between the degree of industrial electrification and the investment share on GDP - taken as a proxy for capital accumulation- in order to see whether there is a link between capital accumulation and the share of primary horsepower electrified. If this did happen we could sustain that the growth of income per capita and productivity was related to the electrification process and the application of the new general purpose technology -electricity.

In Table 8 we can see the relationship between these variables, for the years for which we have data in a majority of countries. There we can observe that the most electrified countries, despite their low economic development in some cases, made a greater effort in capital accumulation and thus in the application of this new technology. This was the case of the USA, Italy, Spain -calculated indirectly-, Sweden, Norway and Japan. In the same table we can see that these countries are among those that experienced considerable increases in labour productivity -GDP per hour worked-, this being the case of the Northern European countries, Norway -2.74and Sweden -1.51-, and, although with a lower rate, that of the Southern countries, Italy -2.01- and Spain ${ }^{35}$-1.76- and Japan -3.42, which started with the lowest level of labour productivity. In relation to the economic growth, as measured by the increase in income per capita, we can also see in the same table that amongst the countries with the highest growth were the Northern European countries, Sweden -2.80 - and Norway -1.96-, the Southern country Spain -1.67- and Japan $-2.37^{36}$.

${ }^{35}$ In Spain labour productivity growth is calculated as the growth of the GDP per labour in 1995 pesetas. In the case of the rest of the countries the data express GDP per hour worked in 1990 Geary-Khamis dollars and PPP. The sources are indicated in Table 8.

${ }^{36}$ However, there are different factors that have influenced the economic growth in the interwar period. The effects of WWI, the economic recovery and the economic crisis of 1929 were different in each country. Economic growth depended on the macroeconomic cycle, as in France, where there was a high growth, and the opposite can be said about Italy, where there was lower growth in 1913-1929. Many more factors, among them new technological changes such as internal combustion, new alloys and materials, transport and communications, and organizational changes such as taylorism, also influenced economic growth in all countries. 
TABLE 8

ELECTRIFICATION, INVESTMENT RATE, LABOUR PRODUCTIVITY AND INCOME PER CAPITA GROWTH, 1913-1929

\begin{tabular}{|l|l|l|c|c|c|c|c|}
\hline Countries & \multicolumn{2}{|l|}{ Electrification (\%) } & \multicolumn{3}{|c|}{ Investment share on GDP (\%) } & $\begin{array}{c}\text { Income per } \\
\text { capita } \\
\text { Growth (\%) }\end{array}$ & $\begin{array}{l}\text { Productivity } \\
\text { Growth (\%) }\end{array}$ \\
\hline & $\mathbf{1 9 2 5}$ & $\mathbf{1 9 2 9}$ & $\mathbf{1 9 1 3}$ & $\mathbf{1 9 2 5}$ & $\mathbf{1 9 2 9}$ & $\mathbf{1 9 1 3 - 1 9 2 9}$ & $\mathbf{1 9 1 3 - 1 9 2 9}$ \\
\hline UK & 49 & 66.3 & 8.2 & 10.0 & 10.4 & 1.43 & 0.24 \\
France & 48.8 & & 14.5 & $13.9^{\mathrm{a}}$ & 16.7 & 2.32 & 1.88 \\
Germany & 66 & 70 & 15.6 & 12.8 & 7.3 & 1.38 & 0.77 \\
USA & 79.1 & 82.3 & 17.5 & 20.6 & 16.2 & 2.37 & 1.65 \\
Canada & 67 & & $18.2^{\mathrm{b}}$ & 15.8 & 22.2 & 1.33 & 0.81 \\
Sweden & 77 & 82.5 & 14.2 & 14.3 & 16.8 & 1.51 & 2.80 \\
Norway & 67 & 73.8 & 20.7 & 18.7 & 19.5 & 2.74 & 1.96 \\
Italy & 74 & 79 & 18.6 & 21.8 & 19.9 & 2.01 & 1.18 \\
Spain & & & 16.2 & 12.4 & 17.1 & $1.76^{\mathrm{c}}$ & 1.67 \\
Japan & 62.2 & 69.4 & $17.7^{\mathrm{b}}$ & 17.4 & $15.9^{\mathrm{d}}$ & 3.42 & 2.37 \\
\hline
\end{tabular}

Sources: Electrification, see Table 6; Investment share on GDP, see Data Appendix; Productivity growth is labour productivity's (GDP per hour worked) annual accumulative growth rate in percentages; Income per capita growth is annual accumulative growth rate in percentages, both of them elaborated from Maddison (1995), pp. 194-201, and 249. GDP, in 1990 GhearyKhamis dollars and PPP. For Spain, Labour productivity growth is GDP per labour elaborated from Prados de la Escosura (2003).

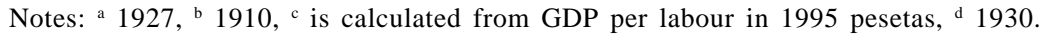

Other implications of electrification were the increase in industry and manufacturing production in the countries with less coal resources, as well as the increase in manufacturing production in the electrified branches of industry in all countries. In Tables 9 and 10, as an approximation, we present the data by industries of: the degree of electrification in 1929, the growth in value added or production -depending on the available sources-, and the shares of each sector in the whole of the manufacturing sector, all of this for two developing countries badly endowed with coal, Italy and Spain, and in two developed countries with good coal endowments, namely the UK and the USA. First, we can see that the increase in manufacturing production was substantially greater in the USA -5.68-, the leading country of the so-called «Second Industrial Revolution»; next came, in this order, Italy -2.64- and Spain -2.27-, whereas the UK exhibits the lowest growth: 1.24. Hence, Italy and Spain grew more than the UK, allowing the manufacturing sector to catch up in the 1920s.

Secondly, inside the manufacturing sector, in spite of having taken into account that there are differences in the composition of branches between countries ${ }^{37}$, the

${ }^{37}$ See the composition in the notes to Tables 9 and 10. 
TABLE 9

ELECTRIFICATION, SHARE AND GROWTH BY MANUFACTURE, 1913-1929 ITALY AND SPAIN

\begin{tabular}{|c|c|c|c|c|c|c|}
\hline \multirow[b]{2}{*}{ Manufactures } & \multicolumn{3}{|c|}{ Italy } & \multicolumn{3}{|c|}{ Spain } \\
\hline & $\begin{array}{c}\text { Electri- } \\
\text { fication } \\
(1927)\end{array}$ & $\begin{array}{l}\text { Share } \\
(1929)\end{array}$ & $\begin{array}{c}\text { Growth } \\
(1913-29)\end{array}$ & $\begin{array}{c}\text { Electri- } \\
\text { fication } \\
\text { (1929) }\end{array}$ & $\begin{array}{l}\text { Share } \\
\text { (1929) }\end{array}$ & $\begin{array}{c}\text { Growt } \\
(1913-29)\end{array}$ \\
\hline $\begin{array}{l}\text { Food, beverage } \\
\text { \& Tobacco }\end{array}$ & 58 & 21.69 & 1.23 & & 42.94 & 2.37 \\
\hline Textile & 86 & 20.45 & 1.14 & 78.3 & 24.90 & 0.46 \\
\hline Leather & & & & & 1.11 & 0.83 \\
\hline Iron \& Steel & & & & 65.6 & 1.52 & 6.00 \\
\hline Metallurgic & 80 & 6.26 & 3.90 & 72.96 & 0.82 & -0.29 \\
\hline Mechanical & 96 & 22.94 & 4.49 & & 11.39 & 5.88 \\
\hline Transport Vehicles & & & & & & \\
\hline $\begin{array}{l}\text { Shipbuilding } \\
\text { Chemicals }\end{array}$ & 71 & 7.83 & 6.68 & 61.34 & 3.53 & 7.68 \\
\hline Paper & & & & & 0.85 & 2.34 \\
\hline Printing & & & & & & \\
\hline Electrical & & & & & & \\
\hline Equipment & & & & & & \\
\hline $\begin{array}{l}\text { \& supplies } \\
\text { Lumber \& }\end{array}$ & & & & & & \\
\hline Woods products & & & & & & \\
\hline \& Furniture & & & & & & \\
\hline $\begin{array}{l}\text { Share of } \\
\text { Manufactures }\end{array}$ & & 79.17 & & & 85.10 & \\
\hline Total Manufactures & 79 & 100 & 2.64 & & 100 & 2.27 \\
\hline
\end{tabular}

Sources: Electrification, see Table 7; Share and Growth, in Italy elaborated from Ercolani (1969); in Spain, elaborated from Carreras (1983).

Notes: Share is share of each manufacture in total manufacturing sector, in percentages; Growth is annual accumulative growth rate in percentages; Share of Manufactures is the sum of the share of each manufacturing in total manufacturing. In Italy, Gross product at factor cost and in Spain, Value added. In Spain, in Mechanical are Metal transformations, where Transport vehicles and Shipbuilding are included; in Metallurgic, iron and steel are excluded.

manufactures experiencing the highest growth were the metallurgical ones or those of iron and steel, depending on the countries, metal transformation or mechanical engineering, and chemicals. These manufactures were amongst the most electrified in Italy, Spain, the UK and the USA. However, in the UK, although amongst the most electrified in the manufacturing branch were the metallurgic, mechanical and transport vehicles, only transport vehicles experienced an important growth.

Thirdly, the sectors with the lowest growth -with respect to the average- in all countries were the textiles and leather. In the UK, among the least electrified 
TABLE 10

ELECTRIFICATION, SHARE AND GROWTH BY MANUFACTURE, 1913-1929 THE UK AND THE USA

\begin{tabular}{|c|c|c|c|c|c|c|}
\hline \multirow[b]{2}{*}{ Manufactures } & \multicolumn{3}{|c|}{ UK } & \multicolumn{3}{|c|}{ USA } \\
\hline & $\begin{array}{c}\text { Electri- } \\
\text { fication } \\
(1930)\end{array}$ & $\begin{array}{l}\text { Share } \\
(1930)\end{array}$ & $\begin{array}{c}\text { Growth } \\
(1913-29)\end{array}$ & $\begin{array}{c}\text { Electri- } \\
\text { fication } \\
(1929)\end{array}$ & $\begin{array}{l}\text { Share } \\
(1929)\end{array}$ & $\begin{array}{c}\text { Growt } \\
(1913-29)\end{array}$ \\
\hline \multicolumn{7}{|l|}{ Food, beverage } \\
\hline \& Tobacco & 79.5 & 17.51 & 0.73 & 75.8 & 10.92 & 6.04 \\
\hline Textile & 38.4 & 13.84 & -1.50 & 83.6 & 13.89 & 4.91 \\
\hline Leather & & & & 88.3 & 2.53 & 3.04 \\
\hline Iron \& Steel & 54.9 & 8.62 & -0.09 & 72.8 & 8.98 & 3.52 \\
\hline Metallurgic & 88.6 & 2.26 & 0.29 & 89.4 & 5.08 & 3.04 \\
\hline Mechanical & 88.6 & 8.47 & 0.97 & 95.7 & 7.16 & 6.50 \\
\hline \multicolumn{7}{|l|}{ Transport } \\
\hline Vehicles & 94.8 & 6.78 & 6.95 & 94.4 & 6.09 & 0.53 \\
\hline Shipbuilding & & 1.41 & & & & \\
\hline Chemicals & 75.8 & 6.78 & 1.35 & 79.7 & 5.68 & 6.71 \\
\hline Paper & 82.2 & 9.75 & 2.69 & 72.1 & 2.56 & 6.86 \\
\hline Printing & & & & 98.2 & 7.30 & 6.27 \\
\hline \multicolumn{7}{|l|}{ Electrical Eq. } \\
\hline \& supplies & & 4.94 & 3.88 & & 4.54 & 10.69 \\
\hline $\begin{array}{l}\text { Lumber \& Woods } \\
\text { products \& }\end{array}$ & & & & & & \\
\hline Furniture & & & & 58.3 & 6.33 & 3.53 \\
\hline Share of & & & & & & \\
\hline Manufactures & & 80.37 & & & 81.05 & \\
\hline Total Manufactures & 66.3 & 100 & 1.24 & 79.1 & 100 & 5.68 \\
\hline
\end{tabular}

Sources: Electrification, see Table 7; Growth and Share: In the UK, elaborated from Feinstein (1972), from the index of industrial production, Tables 51 and 52; share of value added in national income in 1930, from Foreman-Peck (1994), p. 401. In the USA, elaborated from Historical Statistics of the US Colonial Times to 1970, series P 58-67, P 265, P270, S353, S354, S355, S 359, S 360, S 361, S 362, S 363.

Notes: Share means share of each manufacture in the total manufacturing sector in percentages; Growth means annual accumulative growth rate in percentages; Share of Manufactures are the sum of the shares of each manufacturing sector in total manufacturing. In the UK: Textile without Clothing, Iron \& Steel is Ferrous Metal, Metallurgic is Metal Manufacture, Mechanical is Mechanical Engineering, Transport Vehicles, Shipbuilding is not included, Chemicals are Chemicals and allied industries, Paper is Paper and Printing, Electrical Equipment and Supplies is Electrical Engineering. In the USA, in Food, Beverage and Tobacco, Tobacco is not included, and data starts in 1921, Textiles are Textile Mill products and Apparel and other textile products, in Chemicals petroleum and coal products aren't included, Iron \& Steel, Raw steel produced, Metallurgic, Hot rolled iron and steel and copper, Mechanical, Machinery except electrical, Transport Vehicles, Shipbuilding is included. 
manufactures were textiles and iron and steel, which also experienced the lowest growth: as a matter of fact, this was negative between 1913 and 1929. However, the textile sector had a high degree of electrification in the USA, Italy and Spain. Thus, there was an important opportunity to reduce production costs in this sector, and the countries in which the ratio of electricity price to coal price was low took advantage of that opportunity. In Italy, the food industry had a low degree of electrification and also a lower growth in relation to the average. In the case of the USA, the leading country in electrification, all manufactures were highly electrified with the exception of lumber and wood, as we have already commented in the preceding section.

The growth of the manufactures mentioned here -mechanical and chemicalswas substantially higher than the average in Italy and especially in Spain, where these industries had less weight in total manufacturing than their counterparts in the UK and the USA, as we can see in Tables 9 and 10. In the former countries, the manufacturing sector was able to grow while at the same time structural change was taking place. Thus, there had to be a relationship between the process of investment and that of electrification, manufacturing and economic growth, especially for the countries worse endowed in coal stocks.

\section{CONCLUSIONS}

The main conclusion of this article is the importance of the new energy in reducing the dependence on the natural resources of coal for countries that lacked this important mineral, as electricity could be created from different primary energies, water or coal. We started by describing the different natural resources of the countries of this study, with a focus on coal. Next, we presented a database containing the prices of electricity, as indicated by lighting prices, and the prices of the old and alternative energy, steam, as revealed by coal prices. We have shown that the relative prices electricity-coal were lowest in countries that had no good endowments of coal, which implied more opportunities from using the new energy.

We have found that there was a negative relationship between relative prices electricity-coal and economic growth, after controlling for the initial level of per capita income, the accumulation of physical capital, human capital, the UK dummy and the period dummies. Consequently, the countries in which electricity was cheap when compared to coal had the opportunity for greater economic growth during this period.

The degree of electrification advanced substantially from the end of the nineteenth century until WWII, the height of the process being 1925, after WWI, when real electricity prices fell considerably. The behaviour of the relative prices electricity-coal, coupled with the new technical opportunities for electrification in 
the manufacturing sector where electricity competed with steam, produced important possibilities for economic growth. There was also a relationship between the accumulation of physical capital and electrification process and the increase in labour productivity, manufacturing and income per capita, especially in the countries that were badly endowed with coal deposits, but enjoyed better opportunities for the production of electricity.

\section{REFERENCES}

Annuaire Statistique de la France, 1946: Résume Rétrospectif. Paris.

Antolín, F. (1999): «Iniciativa privada y política pública en el desarrollo de la industria eléctrica en España. La hegemonía de la gestión privada, 1875-1950». Revista de Historia Económica XVII (2), pp. 411-445.

Arroyo, M. (1996): La industria del gas en Barcelona, 1841-1933. Innovación tecnológica, territorio urbano y conflicto de intereses. Barcelona: Ediciones del Serbal.

BARDINI, C. (1994): «Ma il vapore era davvero importante? Consumo energetico e sviluppo industriale di un paese privo di carbone (Italia 1885-1914)».Florence: Instituto Universitario Europeo. Unpublished Doctoral Dissertation.

- (1997): «Without Coal in the Age of Steam: A Factor-Endowment Explanation of the Italian Industrial Lag Before World War I». Journal of Economic History 57 (3), pp. 633-552.

- (1998): Senza carbone nell'età del vapore. Gli inizi dell'industrializzazione italiana. Milan: Bruno Mondadori.

Bardini, C., and Hertner, P. (1993): «Decollo elettrico e decollo industriale», in G. Mori (ed.), Storia dell'industria elettrica in Italia. Vol. 1. Le origini. 1882-1914. Bari: Laterza, pp. 201-248.

BarJot, D. (1991): L'energie au XIXe et XXe siècles. Paris: Presses de l'Ecole Normale Supérieur.

Barro, R. J. (1991): «Economic Growth in a Cross Section of Countries». Quarterly Journal of Economics 106 (2), pp. 407-443.

Bresnahan, T., and Trajtenberg, M. (1995): «General Purpose Technologies: Engines of Growth». Journal of Econometrics 65, pp. 83-108.

Carré, J. J., Dubois, P., and Malinvaud, J. P. (1975): French Economic Growth. Stanford: Stanford University Press.

CARRERAs, A. (1983): «La producció industrial espanyola i italiana des de mitjan segle XIX fins a l'actualitat», Bellaterra: Universidad Autónoma de Barcelona, unpublished Ph.D. thesis.

- (1997): «La industrialización, una perspectiva de largo plazo». Papeles de Economía Española 73, pp. 35-60.

- (coord.) (1989): Estadísticas históricas de España. Siglos XIX-XX. Madrid: Fundación Banco Exterior.

Coll, S., and Sudriè, C. (1987): El Carbón en España, 1770-1961. Una Historia Económica. Madrid: Turner.

DARMSTADLER, J. (1971): Energy in the world economy. A statistical review of trends in output, trade, and consumption since 1925. Baltimore: The Johns Hopkins Press. 
David, P. A., and Wright, G. (1999): «General Purpose Technologies and Surges in Productivity: Historical Reflections on the Future of the ICT Revolution». Oxford: University of Oxford. Discussion Papers in Economic and Social History 31.

De Long, B., and Summers, R. (1991): «Equipment Investment and Economic Growth». Quarterly Journal of Economics 106 (2), pp. 445-502.

Devine, W. D. Jr. (1983): «From Shafts to Wires: Historical Perspective on Electrification». Journal of Economic History XLIII (2), pp. 347-372.

Ercolani, P. (1969): «Documentazione statistica di base», in Fua, G. : Lo svilupo economico in Italia. Milan: Franco Angeli Editore, vol. III, pp, 380-460.

Etemad, B., and Luciani, J. (1991): World Energy Production, 1800-1985. Geneva: Libraire Droz.

Feinstein, C. (1972): National Income, Expenditure and Output of the UK, 1855-1965. Cambridge: Cambridge University Press.

FlorA, P. (1973): «Historical processes of social mobilization: urbanization and literacy, 1850-1965» in S.N. Eisenstadt and S. Rokkan: Building states and nations. Models and Data Resources. Beverly Hills \& London: SAGE Publications, vol. I, pp. 213-258.

- (1987): State, economy, and society in Western Europe, 1815-1975: a data handbook in two volumes. Frankfurt: Campus Verlag.

Foreman-Peck, J. (1994): «Industry and industrial organisation in the interwar years», in R. Floud and D. McCloskey (eds.): The Economic History of Britain since 1700. Cambridge: CUP, vol. 2, pp.386-414.

Geological survey of Canada, The (ed.) (1913): The coal reserves of the World. And inquiry made upon the initiative of the Executive Committee of the XII International Geological Congress. Canada: Toronto, Morang \& CO, 3 vols. and Atlas.

Giannetti, R. (1985): La Conquista della Forza. Risorce, Tecnologia ed Economia nell'Industria Elettrica Italiana (1883-1940). Milan: Franco Angeli Libri.

— (1986): «Elettricità e Industrializzazione dall” «Età del Decollo» alla Seconda Guerra Mondiale». Società e Storia 3, pp.595-618.

Goldin, C., and Katz, L. (1998): «The Origins of Technology-Skill Complementarity». Quarterly Journal of Economics 113 (3), pp. 694-732.

HanNah, L. (1979): Electrification before Nationalisation. A Study of the Development of the Electricity Supply Industry in Britain to 1948. London: The Johns Hopkins University Press.

Harley, C. K. (1989): «Coal Exports and British Shipping, 1850-1913». Explorations in Economic History 26, pp. 311-338.

Helpman, E. (ed.) (1998): General Purpose Technologies and Economic Growth. Cambridge, MA: The MIT Press.

Hoover, E. M. (1948): The Location of Economic Activity. New York: McGraw-Hill.

Hugues, T. P. (1983): Networks of Power. Electrification in Western Society, 1880-1930. Baltimore and London: The Johns Hopkins University Press.

IsARD, W. (1956): Location and Space-Economy. Cambridge, MA: The MIT. Press.

Jevons, H. S. (1969) [1915] The British Coal Trade. New York: Augustus M. Kelley Publishers.

Krugman, P. (1991): Geography and Trade. Cambridge, MA: The MIT Press.

Kuznets, S. (1961): Capital in the American Economy. Its formation and Financing. Princeton: Princeton University Press. 
Landes, D. S. (1969): The Unbound Prometheus. Cambridge: Cambridge University Press. Lösch, A. (1954) [1940]: The economics of Location. New Haven and London: Yale University Press.

Maddison, A. (1995): Monitoring the World Economy. Geneva: O.C.D.E.

MALuquer DE Motes, J. (1987): «L'électricité, facteur de développement économique en Espagne: 1900-1936», in F. Caron (ed.), Un siegle d'electricité dans le monde 18801980. Paris: PUF, pp. 57-67.

Ministerio de Trabajo. Dirección General de Estadística (1942): Precios al por mayor y números índices 1913 a 1941. Boletin de Estadística, número extraordinario. Madrid.

Mitchell, B. R. (1962): Abstract of British Historical Statistics. Cambridge: Cambridge University Press.

- (1998): International Historical Statistics: Europe: 1750-1993. New York: Stockton Press.

- (1999): International Historical Statistics: The Americas: 1750-1993. Basingstoke: Macmillan Reference.

Mortara, G. (1934): Nel Cinquentenario della Societá Edison, 1884-1934. Milan: Societá Generale Italiana Edison, 4 volumes.

Myllyntaus, T. (1991): «The Transfer of Electrical Technology to Finland, 1870-1939». Technology and Cultures 32 (2/1), pp. 293-317.

NaKamuRA, T. (1971): Economic Growth in Prewar Japan. New Haven and London: Yale University Press.

NaKamura, T., and Odaka, K. (2003): The Economic History of Japan: 1600-1990. Oxford: Oxford University Press, vol. 3.

Nelson, R. R., and Wright, G. (1992): «The Rise and Fall of American Economic Leadership: the Postwar Europe in Historical Perspective». Journal of Economic Literature 30 (4), pp. 1931-64.

NúÑEz, C. E. (1992): La fuente de la riqueza. Educación y desarrollo económico en la España contemporánea. Madrid: Alianza.

Prados de la Escosura, L. (2003): El progreso económico de España, 1850-2000. Madrid: FBBV.

SCHURR, S.H., and NetsChERT, B. C. (1960): Energy in the American Economy, 1850-1975. An Economic Study of Its History and Prospects. Westport, Connecticut: Greenwood Press.

Somario di statistiche storique dell'Italia, 1861-1965. (1986). Rome.

Storaci, M. and TatTARA, G. (1998): «The External Financing of Italian Electric Companies in the Interwar Years». European Review of Economic History 2 (3), pp. 345-375.

SudRIÀ, C. (1983): «Notas sobre la implantación y el desarrollo de la industria del gas en España, 1840-1901». Revista de Historia Económica I (2), pp. 97-118.

- (1987): «Un factor determinante: la energía», in J. Nadal, A. Carreras and C. Sudrià (comps.), La Economía española en el siglo XX. Una perspectiva histórica. Barcelona: Ariel, pp. 313-327.

- (1990): «La industria eléctrica y el desarrollo económico en España», in J.L. García Delgado (dir.), Electricidad y desarrollo económico: perspectiva histórica de un siglo. Oviedo: Hidroeléctrica del Cantábrico.

- (1995): «Energy as a Limiting Factor to Growth», in P. Martín-Aceña and J. Simpson (eds.), The Economic Development of Spain since 1870. Aldershot: Edward Elgar, pp. 268-309. 
- (1997): «La restricción energética al desarrollo económico de España». Papeles de Economía Española 73, pp. 165-188.

Svennilson, I. (1959): Growth and Stagnation in the European Economy. Geneva: United Nations Economic Commission for Europe.

Urquhart, M. C., et al. (1983): Historical Statistics of Canada. Toronto: MacMillan.

U.S. Department of Commerce (1931): Power-Using Industries of Italy. Washington: Government Printing Office, Trade Information Bulletin No. 772.

- (1975): Historical Statistics of the US, Colonial Times to 1970. Washington DC: Bureau of the Census.

Woolf, E. A. (1984): «Electricity, Productivity, and Labor Saving: American Manufacturing, 1900-1929». Explorations in Economic History 21, pp. 176-191.

WRIGHT, G. (1990): «The Origins of America Industrial Success, 1879-1940». The American Economic Review 80 (4), pp. 651-667.

Wrigley, E. A. (1988): Continuity, Chance and Change. The Character of the Industrial Revolution in England. Cambridge: Cambridge University Press.

Wylie, P. J. (1989): «Technological Adaptation in Canada Manufacturing, 1900-1929». Journal of Economic History XLIX (3), pp. 569-591.

\section{APPENDIX}

\section{Data sources:}

Prices of energy

Real energy prices for each country are energy prices deflated by their corresponding wholesale price indexes, in 1913 fixed prices, from Mitchell, B.R. (1998) and (1999).

\section{Electricity:}

1) France

- Annuaire Statistique de la France, 1946: Résume Rétrospectif. Tableau XI. Prix moyen de l'electricite pour l'eclairage privé. Average Lighting. (1914, 1920, 1928, 1930-1945). In francs and cents per kWh.

2) Italy

- Somario di statistiche storique dell'Italia, (energia elettrica per illuminazione, Comune di Milano). Lighting (1921-1942). In lire per kWh.

3) the USA

- Historical Statistics of the US, Colonial Times to 1970, p. 827. Household (residential service, as in Svennilson (1959)) (1902, 1907, 1912, 1917, 1920-1945), Large light and Power (average price, the same as in Svennilson (1959), 1917, 1922, 1926-1945). Average prices all services (1907, 1917, 1922, 1926-1945), these averages indicate the average revenue from electric service and will vary with the average use and the rate levels. In cents per kWh.

4) the UK

- Hannah (1979). Average prices per kWh. Sold (Average revenue per kWh sold): Total, Lighting \& Heating, Power and Traction. (1921-1948). (In Svennilson (1959), the same data). In pence per kWh sold. 
5) Canada

- Urquhart et al. (1983). From the revenues and sales we calculate the Average price (Revenue/Sales), Average revenue per kWh. sold: Residential and Farms, Commercial, Industrial, Street Lighting, and Total Domestic. (1930-1944). In dollars (Can.) per kWh.

6) Spain

- Anuario Estadístico de España, several years and Precios al por mayor y números índices 1913 a 1941. Lighting (Fluido Eléctrico) (1913-1941). In pts per kWh.

Coal:

1) France

- Barjot, D. (1991). Prix de la tonne de houille sur les marchés intérieurs, 1901-1944. (Francs per ton.).

2) Italy

- Sommario di Statistiche Storiche dell'Italia. Carbone fossile da gas in Prezzi all'ingrosso. (lire/ton.). (1881-1890, 1891-1900, 1901-1910, 1911-1920, 1921-1943, the last period by year, the others an average).

3) the USA

- Historical Statistics of the US. Colonial Times to 1970, Vol.1. Coal (anthracite) in Wholesale prices selected commodities: 1800 to 1970. (Dollars/ton).

4) the UK

- Mitchell, B.R. (1962). Coal (All exports). (Shillings/tonne). (Conversion 1 pence $=12$ shilling).

5) Canada

- Urquhart et al. (1983). Coal (in production of fuels). From the quantities and values, we calculate the prices (dollars (Can)/tonne), (1890-1945).

6) Spain

- Anuario Estadístico de España, several years, and Precios al por mayor y números índices 1913 a 1941. Coal (national production): carbón cribado, (1913-1941). In pts per tonne.

- Coll and Sudrìa (1987, pp.422-423).

Energy production: electricity, by sources, and coal for each country in Etemad and Luciani (1991).

Consumption by uses: the USA, Statistics of the US Colonial Times to 1970, p. 132; the UK (sales), Hannah (1979), pp. 427-429; Canada (sales), Urquhart et al. (1983), pp. 102-106.

G.D.P. per capita: (in 1990 Gheary-Khamis dollars and PPP) from Maddison (1995).

Investment share on GDP: the USA, Net Capital Formation, current prices from Kuznets (1961), pp. 572-574; France, investment ratio from Carré, Dubois and Malinvaud (1975), pp. 528; Spain, from Carreras, A. (1997), p. 42; Japan, from Nakamura (1971), p. 5. The rest of countries from Mitchell (1998).

\section{Education:}

- Literacy: percentage of the population over 10-12 years old able to read and write in the initial year of each period. Linear interpolation to obtain data of the initial year. 
- USA: Historical Statistics of the US Colonial Times to 1970, series H, 664-668 (10+). France and Italy: Flora (1987) (10+ and 12+). UK: Flora (1973). Spain: Núñez (1992) $(10+)$.

- Schooling: primary school enrolment as a percentage of the population aged 5 to 14 years old in the initial year of each period.

- USA: Calculated from Historical Statistics of the US Colonial times to 1970, series H 412-432 and A 119-134. France, Italy and the UK: Flora (1987), pp. 578, 559, 624. Spain: Calculated from Núñez (1992), pp. 229, 240, and Carreras (coord.) (1989), p. 69, as well as the yearbooks of the Instituto Nacional de Estadistica.

Electrification: sources appear quoted by authors in the tables except for Spain, for which they are taken from Anuario Estadístico de España (AEE), and Estadísticas Mineras y Metalúrgicas de España (EMM). 